\title{
Combined impacts of current and future dust deposition and regional warming on Colorado River Basin snow dynamics and hydrology
}

\author{
J. S. Deems ${ }^{1,2}$, T. H. Painter ${ }^{3}$, J. J. Barsugli ${ }^{1,4}$, J. Belnap ${ }^{5}$, and B. Udall ${ }^{6}$ \\ ${ }^{1}$ CIRES NOAA Western Water Assessment, University of Colorado, Boulder, CO, USA \\ ${ }^{2}$ CIRES National Snow and Ice Data Center, University of Colorado, Boulder, CO, USA \\ ${ }^{3}$ NASA Jet Propulsion Laboratory/California Institute of Technology, Pasadena, CA, USA \\ ${ }^{4}$ NOAA Earth System Research Laboratory, Physical Sciences Division, Boulder, CO, USA \\ ${ }^{5}$ United States Geological Survey, Moab, UT, USA \\ ${ }^{6}$ Getches-Wilkinson Center, University of Colorado School of Law, Boulder, CO, USA \\ Correspondence to: J. S. Deems (deems@nsidc.org)
}

Received: 25 March 2013 - Published in Hydrol. Earth Syst. Sci. Discuss.: 17 May 2013

Revised: 20 September 2013 - Accepted: 7 October 2013 - Published: 7 November 2013

\begin{abstract}
The Colorado River provides water to 40 million people in seven western states and two countries and to 5.5 million irrigated acres. The river has long been overallocated. Climate models project runoff losses of 5-20\% from the basin by mid-21st century due to human-induced climate change. Recent work has shown that decreased snow albedo from anthropogenic dust loading to the $\mathrm{CO}$ mountains shortens the duration of snow cover by several weeks relative to conditions prior to western expansion of the US in the mid-1800s, and advances peak runoff at Lees Ferry, Arizona, by an average of 3 weeks. Increases in evapotranspiration from earlier exposure of soils and germination of plants have been estimated to decrease annual runoff by more than 1.0 billion cubic meters, or $\sim 5 \%$ of the annual average. This prior work was based on observed dust loadings during 2005-2008; however, 2009 and 2010 saw unprecedented levels of dust loading on snowpacks in the Upper Colorado River Basin (UCRB), being on the order of 5 times the 2005-2008 loading. Building on our prior work, we developed a new snow albedo decay parameterization based on observations in 2009/10 to mimic the radiative forcing of extreme dust deposition. We convolve low, moderate, and extreme dust/snow albedos with both historic climate forcing and two future climate scenarios via a delta method perturbation of historic records. Compared to moderate dust, extreme dust absorbs $2 \times$ to $4 \times$ the solar radiation, and shifts
\end{abstract}

peak snowmelt an additional 3 weeks earlier to a total of 6 weeks earlier than pre-disturbance. The extreme dust scenario reduces annual flow volume an additional 1\% $6 \%$ compared to pre-disturbance), a smaller difference than from low to moderate dust scenarios due to melt season shifting into a season of lower evaporative demand. The sensitivity of flow timing to dust radiative forcing of snow albedo is maintained under future climate scenarios, but the sensitivity of flow volume reductions decreases with increased climate forcing. These results have implications for water management and suggest that dust abatement efforts could be an important component of any climate adaptation strategies in the UCRB.

\section{Introduction}

The Colorado River provides fresh water to over 40 million people in seven states and two countries and to 5.5 million irrigated acres. Anthropogenic warming and enhanced evapotranspiration over the coming decades put this supply at risk. Coupled climate-hydrology model simulations show a 5-20\% decrease in flow depending on the study, indicative of a greater risk of a dry future (Christensen et al., 2004; Christensen and Lettenmaier, 2007; McCabe and Wolock, 2007; Barnett et al., 2005; Barnett and Pierce, 2009; Bureau of 


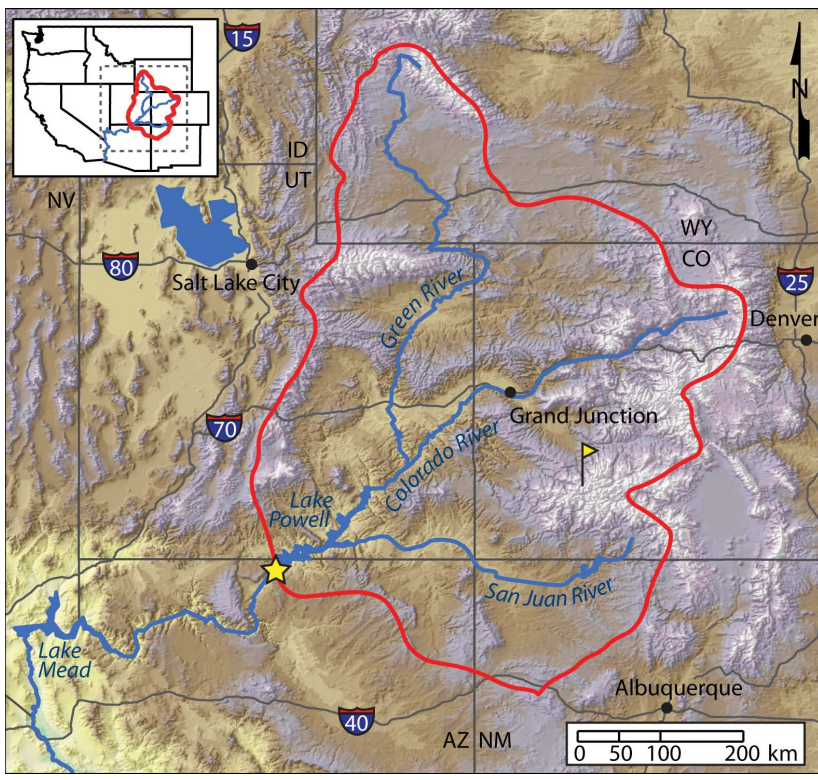

Fig. 1. Map of Upper Colorado River Basin.

Reclamation, 2011a, b; Colorado Water Conservation Board, 2012; Vano et al., 2012; Seager et al., 2012).

The Colorado River receives the bulk of its annual flow from snowmelt in the upper basin (Fig. 1). The major reservoirs on the river, Lake Mead in the lower basin and Lake Powell near the outflow from the upper basin, and the other reservoirs in the Colorado River Storage Project, allow storage of approximately four times the average annual runoff. The upper basin above these major reservoirs has significantly less storage. Many upper basin water managers and users depend predominately on storage of water in the snowpack to delay runoff for use in the drier late spring and summer seasons. Changes in snowmelt forcing, whether from warming or dust, can have a large impact on the availability of stored and in-stream water resources during the drier season.

Absorbed (net) solar radiation dominates the snow surface energy balance during the melt season at mid-latitude sites (Oerlemans and Klok, 2002; Bales et al., 2006). Dust has been observed to reduce melt season snow albedo from 0.7 for clean snow down to near 0.3 , more than doubling absorbed solar radiation (Painter et al., 2012a).

Dust loading ( $\mathrm{kg}$ dust per $\mathrm{m}^{2}$ ) and the above associated radiative forcings of the magnitude observed in the San Juan Mountains of southwestern Colorado over the period 2005-2008 shortens snow cover duration by 25 to 35 days through its reduction of snow albedo and the resulting enhancement of solar radiation absorption (Painter et al., 2007). Daily radiative forcing of snowmelt by dust in this region can exceed present-day (and likely future) greenhouse gas forcings by two orders of magnitude. When extended to the entire Upper Colorado River Basin (UCRB) above Lees Ferry,
AZ, the 2005-2008 dust radiative forcing in snow on average shifted peak runoff more than 3 weeks earlier than under pre-settlement conditions, and reduced annual runoff by $\sim 5 \%$ through enhanced sublimation and evapotranspiration (ET; Painter et al., 2010).

Spring 2009 brought an order of magnitude increase in dust deposition to the mountains of the UCRB over that observed in 2005-2008, quantified by observations in the Senator Beck Basin study area in the San Juan Mountains of Colorado (Painter et al., 2012a; Skiles et al., 2012). Snow albedo dropped below 0.35 for the last 3 weeks of the season, whereas in previous years albedos were never consistently below 0.5 . The acceleration of snowmelt resulted in the most rapid melt rates in the period of record for many SNOTEL sites in the UCRB. The mean spring radiative forcing by dust in snow was $111 \mathrm{Wm}^{-2}$, producing a 48-day reduction of snow cover duration, representing an additional 20 day reduction over the previous dust impacts during 20052008, which experienced a dust radiative forcing range of $25-50 \mathrm{Wm}^{-2}$ (Skiles et al., 2012).

The year 2010 produced levels of dust deposition on the UCRB snowpack similar to 2009, with only slightly lower end-of-year dust concentrations (parts per thousand by weight of dust in snow) (Painter et al., 2012a). A wet spring with abundant snowfall that buried much of the dust kept snow albedos high until late in the melt season, effectively compressing the period of snowmelt but still resulting in a 40-day reduction in snow cover duration (Skiles et al., 2012). Taken together, 2009 and 2010 offered a startling glimpse into the potential magnitude of dust deposition on UCRB snowpacks, and into a possible "future normal" dust condition and associated impacts under regional warming (Munson et al., 2011).

From analysis of dust loading in lake sediments in the mountains of the UCRB (Neff et al., 2008; Reynolds et al., 2009), we know that the sustained disturbance of previously stable lands in the Colorado Plateau and Great Basin that began in the latter half of the 1800 s has led to a five-fold increase in dust deposition over that of the pre-settlement conditions of the previous 1000-3000 yr. This sustained level of increased dust production and deposition appears to have been increasing further over recent decades (Brahney et al., 2013), and recent hydrologic studies show it has been affecting snowmelt rates and runoff timing and volume from the Colorado River Basin (Painter et al., 2007, 2010; Skiles et al., 2012). Though some global dust sources exceed the intensity of dust emission in the southwestern US (e.g., Yu et al., 2012), multiple lines of evidence, including backtrajectory analysis, dust particle sizes, and synoptic event drivers, demonstrate the primarily regional provenance of dust deposited on UCRB snowpacks (Painter et al., 2007; Neff et al., 2008; Lawrence and Neff, 2009; Lawrence et al., 2010; Steenburgh et al., 2012).

Based on this evidence, we hypothesize that the accelerated melt associated with this dramatic post-settlement 
increase in dust deposition (and recent enhancements) has affected the basin hydrograph and ultimately decreased yield by increasing losses due to sublimation and evapotranspiration. Our initial modeling suggests that the increased dust loading (represented by a modified snow albedo parameterization) has markedly modified the hydrograph and decreased annual water yield in the UCRB (above Lees Ferry, AZ) by an average of $5 \pm 3 \%$, or $1.0 \pm 0.7$ billion cubic meters (BCM), since significant dust deposition began (Painter et al., 2010), with a total loss of yield of 90 BCM during 1915-2003.

Several studies have shown decreasing trends in peak snow accumulation in the UCRB over the past century (e.g., Hamlet et al., 2005; Barnett et al., 2005; Mote, 2006) and projections of future climate scenarios point to decreases in streamflow due to atmospheric warming and, in many simulations, decreases in precipitation (e.g., Christensen et al., 2004; Christensen and Lettenmaier, 2007; Seager et al., 2007, 2012). Climate warming has also been projected to increase the frequency and severity of drought in the southwestern US (e.g., Cayan et al., 2010), precipitation variability (e.g., Dominguez et al., 2012), and thus the areal expanse of desert regions. These responses will likely increase the frequency and magnitude of dust emission from deserts in the southwestern US under continued levels of soil disturbance (Belnap et al., 2009; Munson et al., 2011). The impacts of a warming climate on snow accumulation, snowmelt, and UCRB runoff would be strongly accelerated by increased dust emission and deposition on mountain snowpacks. By contrast, modified land management practices in desert systems of the Colorado Plateau and Great Basin may provide a means to increase runoff or reduce losses.

It is critical, in this period of intense ongoing study of, and planning for, scenarios of future Colorado River flow, to examine the relative and combined impacts of dust and regional warming on snow accumulation and melt in the UCRB. In this study, we adopt a model sensitivity approach that follows up on our earlier efforts (Painter et al., 2010) to examine a range of future dust and climate scenarios to help guide future studies, aid in scenario planning, and guide development of land and water management strategies.

\section{Hydrologic modeling and climate perturbations}

\subsection{VIC modeling}

We used the Variable Infiltration Capacity (VIC) hydrologic model (Liang et al., 1994) to simulate the naturalized runoff (effects of water management removed) from the UCRB at Lees Ferry, Arizona, under enhanced dust loading and compare the results to pre- and post-disturbance dust loading results from Painter et al. (2010) by using identical meteorological inputs. The VIC model has been applied in numerous hydrology-climate change studies in the western US (Bar-
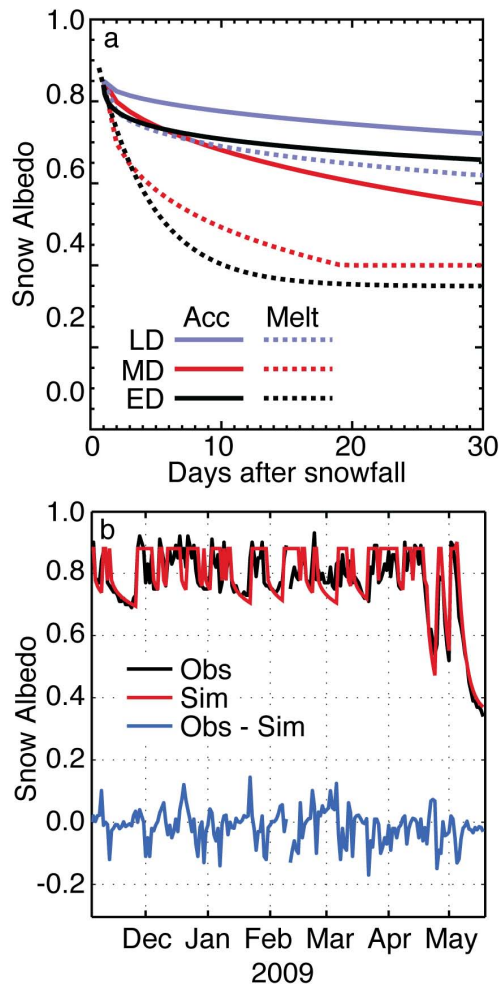

Fig. 2. (a) Snow albedo decay curves for moderate dust (MD), low dust (LD), and extreme dust (ED) deposition scenarios. (b) Time series of observed 2009 albedos at Swamp Angel Study Plot in Senator Beck Basin, CO, simulated ED snow albedos, and residuals.

nett et al., 2005; Hamlet et al., 2005, 2007; Mote et al., 2005; Christensen and Lettenmaier, 2007) and globally (Nijssen et al., 2001; Su et al., 2006). As in our earlier study (Painter et al., 2010), we run VIC at $1 / 8^{\circ}$ latitude and longitude resolution at a daily time step for the period 1915 to 2003, forced with meteorology derived from the NWS Cooperative observation (COOP) network (Hamlet et al., 2007). We discarded output from 1915 to allow the model state variables to stabilize and analyzed the outputs from 1916 to 2003.

\subsection{Snow albedo scenarios}

As in the previous study (Painter et al., 2010), we used a sensitivity approach to examine the hydrologic impacts of different dust deposition/snow albedo regimes. We refer to dust loading prior to disturbance of western lands as the low dust loading scenario (LD) and conditions based on observations over the 2003-2008 time period as moderate dust loading scenario (MD). In order to examine the impacts of extreme dust deposition observed in 2009 and 2010, we created the extreme dust loading scenario (ED) to match the rates of snow albedo decrease observed in those years at micrometeorological stations located at the Senator Beck Basin study site (Fig. 2a and b) (Painter et al., 2012a). 


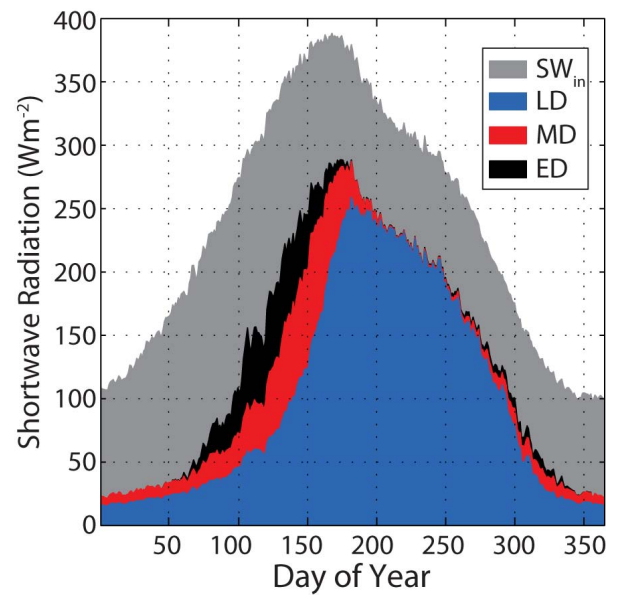

Fig. 3. Model period daily average simulated incoming shortwave radiation, and daily average net shortwave input to the snow cover under low dust (LD), moderate dust (MD), and extreme dust (ED) dust loading scenarios.

Snow albedo values in the VIC model are derived via albedo decay curves relating snow albedo to the number of days since snowfall. The MD albedo decay curves closely match albedo observations at SBB over 2005-2008 (referred to as the ADL, or after-disturbance loading scenario, in Painter et al., 2010). The LD decay curves were derived from albedo measurements from mountain regions that currently receive low levels of dust deposition (Painter et al., 2010). The ED accumulation season curve decreases more quickly than the MD curve through day 5 post-snowfall, then decays more slowly, an artifact of the late winter weather patterns during 2009 and 2010. A longer record of extreme dust deposition years would likely result in an ED decay curve for the accumulation season that is below the MD curve at all time lags rather than our paradoxical result which shows MD curve dropping below ED at longer lags. The ED melt season curve, by contrast, illustrates the extremely rapid albedo decay rates observed during the 2009 and 2010 melt seasons.

Compared to the MD scenario, solar radiation absorption by the snow cover is reduced under the LD scenario and enhanced under ED (Fig. 3). Maximum melt season changes in net solar radiation exceed $150 \%$ of MD under ED dust loadings and show reductions of $35 \%$ under LD conditions as compared to MD.

We applied the snow albedo scenarios uniformly across the UCRB domain, lacking observations of the spatial distribution of dust loading or radiative forcing for sufficient duration to specify the dust/albedo time series. Recent work has quantified the non-uniform nature of the spatial variability of dust radiative forcing in the UCRB using data from the MODIS instrument for the time period 2000-2013 (Painter et al., 2012b). Our spatially uniform application is therefore a simplification, consistent with our sensitivity approach, and likely overestimating dust impacts in portions of the domain while underestimating it in others.

\subsection{Climate scenarios}

To examine the interaction of the above dust scenarios with projected future climate states, we conducted climate sensitivity experiments guided by the changes seen in an ensemble of climate model projections. We generated a small set of representative future climate time series using the delta method, where monthly climate change factors derived from climate models are applied to historical observational data. The simplicity of this approach is consistent with the sensitivity approach used with the dust deposition/albedo decay scenarios, and has the advantage of maintaining realistic daily sequences of climate state variables; the interannual variability under the climate scenarios is provided by the historic time series. Because snowpack accumulation and melt are the result of cumulative precipitation and the cumulative surface energy balance, any potential changes in the detailed daily sequences that we neglect are less important than changes in monthly averages.

The climate models used to determine the perturbation are listed in Table 1. This dataset of daily model output from CMIP3 was chosen because it contains information on $T_{\min }$ and $T_{\max }$ that is lacking in the monthly CMIP3 archives. The daily minimum temperature, maximum temperature, and total precipitation were obtained for three periods (recent past [1961-2000], mid-century [2046-2065], and end of century [2081-2100]) for the SRES B1 and A2 carbon emissions scenarios (Solomon et al., 2007). We obtained re-gridded daily global climate model (GCM) output from the Bureau of Reclamation (L. Brekke, personal communication, 2010). This model output has since been used in the production of the Bias-Corrected Constructed Analog daily downscaled data and is available from http://gdo-dcp.ucllnl. org/downscaled_cmip_projections. The gridding methodology is referenced on that website. Monthly climatologies were computed over the three time periods for each model run. Because the models are not evenly represented in this ensemble, we averaged the individual runs of each model first and then treated the single model averages equally in our multi-model average. We refer to this as the "run-averaged ensemble".

\subsection{Upper Colorado River Basin precipitation and temperature changes}

We averaged the $T_{\max }, T_{\min }$, and precipitation values in the GCM grid cells representing the rectangle from $36^{\circ}$ to $44^{\circ} \mathrm{N}$ latitude and $104^{\circ}$ to $114^{\circ} \mathrm{W}$ longitude. This area encompasses the UCRB with a total of $202^{\circ} \times 2^{\circ}$ grid cells. The monthly changes in $T_{\min }$ and $T_{\max }$ for the two time periods (mid-century and end of century) are shown in Fig. 4a, b. Winter (December-March) $T_{\min }$ increases more than $T_{\max }$, 
Table 1. CMIP-3 models used to develop the delta perturbations.

\begin{tabular}{lr}
\hline Model & Run Numbers \\
\hline cccma_cgm3_1 & $1,2,3$ \\
cnrm_cm3 & 1 \\
gfdl_cm2_0 & 1 \\
gfdl_cm2_1 & 1 \\
ips1_cm4 & 1 \\
miroc3_2_medres & 1,2 \\
miub_echo_g & $1,2,3$ \\
mpi_echam5 & 1 \\
mri_cgcm2_3_2a & $1,2,3,4,5$ \\
\hline
\end{tabular}
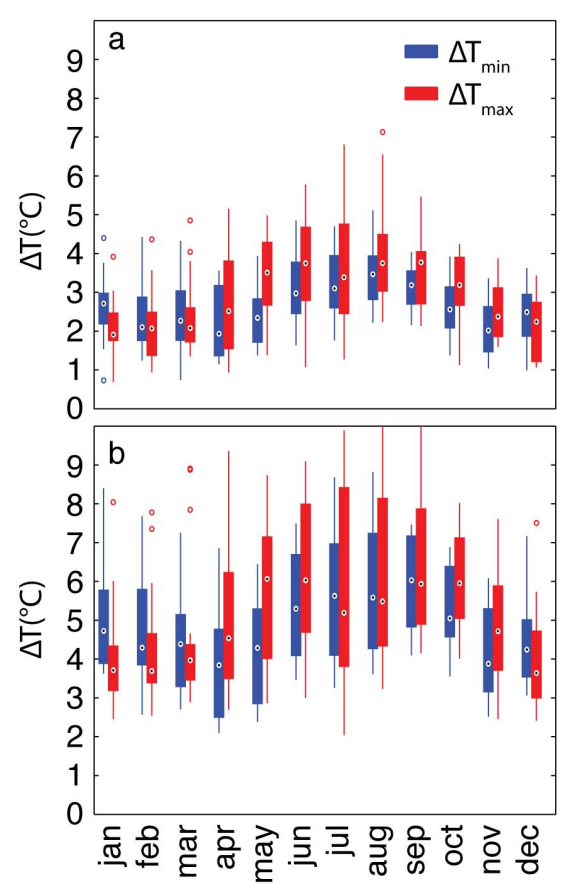

Fig. 4. Change in $T_{\min }$ (blue) and $T_{\max }$ (red) for (a) mid-century, and (b) end of century. The box and whiskers depict the 25th, median, and 75th percentiles of the range of the 9 models considered. The individual runs of each model have been averaged to create a single ensemble member for each model.

as shown by the median in the box-and-whisker depiction. During the rest of the year, $T_{\max }$ increases more than $T_{\min }$, with the exception of July. May shows the greatest difference, with $T_{\max }$ increasing $\sim 1.5 \mathrm{~K}$ more than $T_{\min }$ by the end of the century.

Precipitation changes are shown in Fig. 5a, b for absolute and percentage changes. (Note that in contrast to Fig. 4, the two colors show the two periods rather than the different aspects of temperature.) The precipitation changes show the typical model-projected pattern of increased winter precipitation and decreased late spring and summer precipitation for this region (Ray et al., 2008), with considerable spread from model to model. The mean values of the changes for the
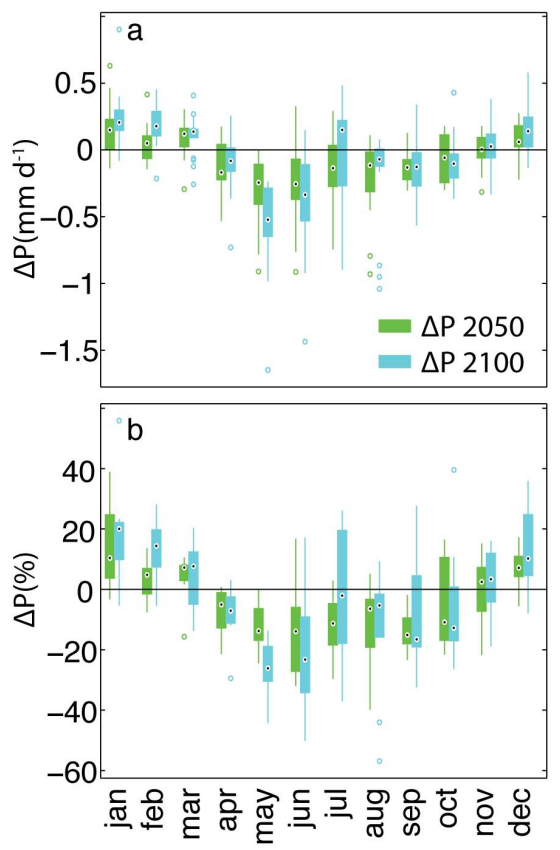

Fig. 5. Change in precipitation expressed as (a) $\mathrm{mm} \mathrm{day}^{-1}$ and (b) percentage for mid-century (green) and end of century (light blue).

Table 2. Delta perturbations for SRES B1 emissions scenario, for decade centered on 2050 and decade ending in 2100.

\begin{tabular}{lccc|ccc}
\hline & \multicolumn{3}{c|}{2050} & \multicolumn{3}{c}{2100} \\
\cline { 2 - 7 } Month & Prcp & $T_{\max }$ & $T_{\min }$ & $\operatorname{Prcp}$ & $T_{\max }$ & $T_{\min }$ \\
\hline 1 & 1.07 & 1.67 & 1.88 & 1.11 & 2.47 & 2.78 \\
2 & 1.02 & 1.34 & 1.92 & 1.03 & 2.54 & 2.92 \\
3 & 1.01 & 1.64 & 1.67 & 1.02 & 2.44 & 2.37 \\
4 & 0.96 & 2.51 & 2.00 & 0.97 & 3.41 & 2.80 \\
5 & 0.92 & 2.61 & 1.86 & 0.92 & 3.21 & 2.46 \\
6 & 0.98 & 3.06 & 2.21 & 0.96 & 3.96 & 3.11 \\
7 & 0.96 & 2.94 & 2.57 & 1.01 & 3.54 & 3.27 \\
8 & 0.98 & 2.92 & 2.61 & 0.97 & 3.92 & 3.41 \\
9 & 1.06 & 3.24 & 2.67 & 0.99 & 4.14 & 3.37 \\
10 & 0.98 & 2.90 & 2.29 & 0.99 & 3.80 & 3.09 \\
11 & 1.15 & 2.18 & 1.42 & 1.14 & 3.38 & 2.42 \\
12 & 1.04 & 1.82 & 2.09 & 1.04 & 2.72 & 2.99 \\
\hline Mean & 1.01 & 2.40 & 2.10 & 1.01 & 3.29 & 2.92 \\
\hline
\end{tabular}

run-averaged ensemble of nine models are shown in Table 2 (scenario B1; Nakicenvoic et al., 2000) and Table 3 (scenario A2; Nakicenvoic et al., 2000). These are the values used to perturb the historic inputs to VIC.

\subsection{Separate forcing of $T_{\max }$ and $T_{\min }$}

Climate observations show differing seasonal signals in $T_{\max }$ and $T_{\min }$ trends, with $T_{\min }$ increasing faster than $T_{\max }$ in winter months and vice versa in summer (e.g., Knowles et al., 
Table 3. Delta perturbations for SRES A 2 emissions scenario, for decade centered on 2050 and decade ending in 2100.

\begin{tabular}{lccc|ccc}
\hline & \multicolumn{3}{c|}{2050} & & \multicolumn{3}{c}{2100} \\
\cline { 2 - 6 } Month & Prcp & $T_{\max }$ & $T_{\min }$ & $\operatorname{Prcp}$ & $T_{\max }$ & $T_{\min }$ \\
\hline 1 & 1.14 & 2.07 & 2.48 & 1.19 & 4.17 & 4.98 \\
2 & 1.03 & 1.74 & 2.12 & 1.14 & 4.04 & 4.72 \\
3 & 1.04 & 2.04 & 2.07 & 1.05 & 4.44 & 4.37 \\
4 & 0.92 & 3.01 & 2.30 & 0.92 & 5.51 & 4.40 \\
5 & 0.87 & 3.31 & 2.36 & 0.75 & 5.91 & 4.46 \\
6 & 0.86 & 4.16 & 3.21 & 0.80 & 6.96 & 5.71 \\
7 & 0.88 & 4.04 & 3.47 & 0.99 & 6.44 & 6.27 \\
8 & 0.88 & 4.22 & 3.51 & 0.88 & 6.82 & 6.21 \\
9 & 0.87 & 4.14 & 3.27 & 0.92 & 7.24 & 6.27 \\
10 & 0.95 & 3.40 & 2.69 & 0.94 & 6.40 & 5.39 \\
11 & 1.00 & 2.88 & 1.92 & 1.03 & 5.28 & 4.12 \\
12 & 1.07 & 2.52 & 2.89 & 1.14 & 4.52 & 4.89 \\
\hline Mean & 0.96 & 3.13 & 2.69 & 0.98 & 5.64 & 5.15 \\
\hline
\end{tabular}

2006; Rangwala et al., 2012). In order to faithfully represent the observed diurnal and seasonal patterns of regional climate warming in recent decades, we use separate delta perturbations for $T_{\max }$ and $T_{\min }$, as the warming trends produced by the GCMs broadly match the patterns in the observational datasets: $T_{\min }$ increases faster than $T_{\max }$ in the cool season and the opposite occurs in the warm season. Perturbing $T_{\max }$ and $T_{\min }$ separately should produce more realistic temperature shifts, and therefore changes in sensible and latent heating and long-wave radiative forcings, than a single delta offset for $T_{\text {avg. }}$.

However, our modeling effort is limited by the driving data source, observed daily $T_{\max }$ and $T_{\min }$, from which other energy balance components must be empirically derived. The VIC model uses the method of Thornton and Running (1999) to derive daily incoming solar radiation $\left(\mathrm{SW}_{\mathrm{in}}\right)$ from the diurnal temperature range. This methodological choice is essential for allowing the historic simulations to extend back to 1915 using the COOP meteorological data.

Figure 6 illustrates the change in $\mathrm{SW}_{\text {in }}$ under the future climate scenarios: the diurnal temperature range is decreased in cool season months and increased in warm season months, producing reduced cool season $\mathrm{SW}_{\text {in }}$ and enhanced warm season and snow ablation season $\mathrm{SW}_{\text {in }}$. Net solar radiation dominates the snow energy balance in the UCRB (Painter et al., 2012a; Skiles et al., 2012); thus this separate perturbation of $T_{\max }$ and $T_{\min }$ clearly exerts an additional forcing on snowmelt. However, changes in incident solar radiation due to changes in cloud cover and total column water vapor are to be expected with climate change. For example, Solomon et al. (2007) show a decrease in annual cloudiness for the Colorado River Basin for their multi-model mean. Rangwala et al. (2012) found a $5 \%$ increase in spring season $\mathrm{SW}_{\text {in }}$ in two of the regional climate models examined. Pierce et

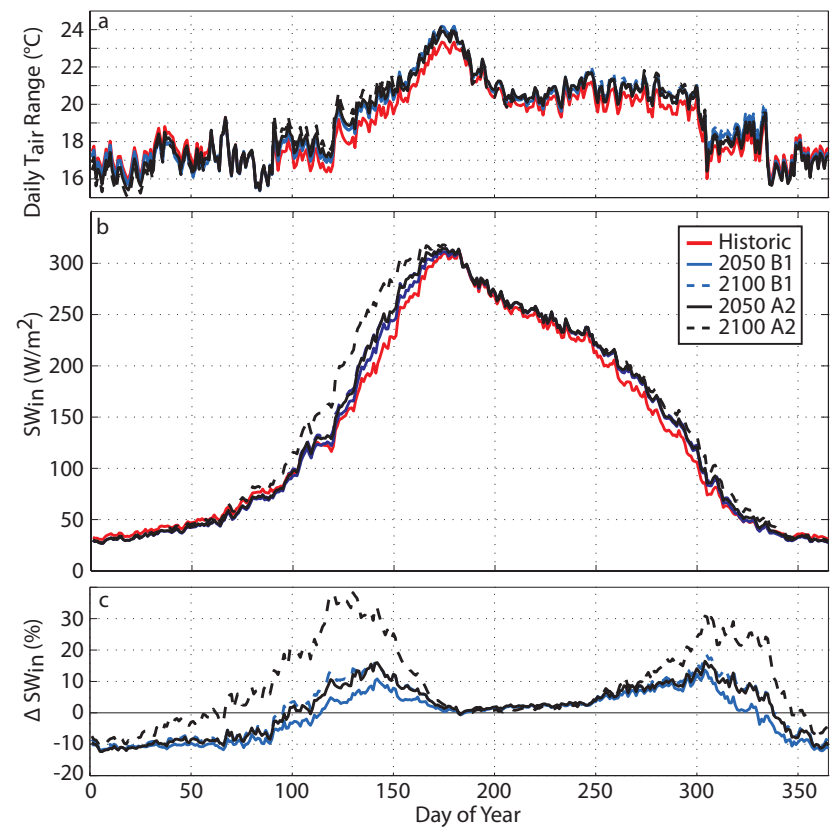

Fig. 6. (a) Daily average temperature range and (b) daily average incoming shortwave radiation under current and future climate scenarios; (c) daily average change in incoming shortwave radiation.

al. (2013) show a trend towards increased aridity in the southwestern US and UCRB, which would increase solar radiation transmission and evaporative losses. They also demonstrate a bias in relative humidity trends calculated by VIC from daily $T_{\max }, T_{\min }$, and precipitation forcing data, with future $\mathrm{RH}$ decreases of smaller magnitude than those predicted by GCMs due to divergent trends in GCM- and VIC-calculated dew point temperature. Their results suggest that this bias could result in end-of-century decreases in UCRB runoff on the same order of magnitude as the dust scenarios detailed in Painter et al. (2010), which would in turn suggest that our results concerning change in runoff due to combined dust and climate forcing are conservative.

Nevertheless, it is difficult to ascertain what, if any, bias has resulted from our separate $T_{\max }$ and $T_{\min }$ perturbations, or to what degree the enhanced fidelity in representation of temperature trends is offset by uncertainties in derived $\mathrm{SW}_{\text {in }}$. We have no a priori reason to suspect that the empirical solar radiation formulation would be any less valid under projected future climate conditions than under the historic climate, as it was developed for a large range of climate conditions and represents a diagnostic relationship between temperature and these energy balance components. However, to bracket this uncertainty, we performed a second set of simulations where $T_{\min }$ and $T_{\max }$ were perturbed equally $\left(T_{\mathrm{avg}}\right.$ delta). This is equivalent to the conservative assumption that solar radiation incident on the surface does not change. The $T_{\text {avg }}$ perturbation results in only slightly smaller reductions of annual streamflow than does perturbation of $T_{\max }$ and 
Table 4. Comparison of change in average annual runoff for 2050 and 2100 under $\mathrm{B} 1$ and $\mathrm{A} 2$ scenarios modeled by perturbing $T_{\max }$ and $T_{\min }$ both separately and equally $\left(T_{\mathrm{avg}}\right)$.

\begin{tabular}{llcccc}
\hline & & $\Delta Q$ & $\Delta Q$ & $\Delta Q$ & $\Delta Q$ \\
& & $(\mathrm{BCM})$ & $(\%)$ & $(\mathrm{BCM})$ & \begin{tabular}{c}
$\Delta \%)$ \\
\cline { 2 - 5 }
\end{tabular} \\
\cline { 3 - 6 } & & $\mathrm{B} 1$ & $\mathrm{~B} 1$ & $\mathrm{~A} 2$ & $\mathrm{~A} 2$ \\
\hline \multirow{2}{2}{050} & $T_{\mathrm{avg}}$ & -2.24 & -11.0 & -4.04 & -19.9 \\
& $T_{\max / \min }$ & -2.39 & -11.8 & -4.16 & -20.4 \\
\hline \multirow{2}{*}{2100} & $T_{\mathrm{avg}}$ & -2.75 & -13.5 & -4.64 & -22.8 \\
& $T_{\max / \min }$ & -2.93 & -14.4 & -4.77 & -23.4 \\
\hline
\end{tabular}

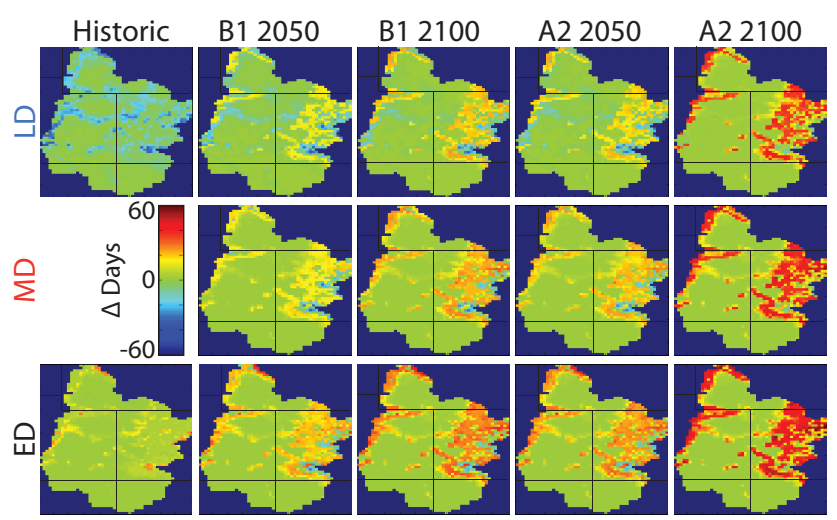

Fig. 7. Change in snow-all-gone dates compared to historic climate, moderate dust (MD) results by grid cell for all dust/albedo scenarios using $\mathrm{B} 1$ and $\mathrm{A} 2$ emissions scenarios.

$T_{\min }$ separately (Table 4). For example, in the MD 2050 B1 case, the $T_{\text {avg }}$ method results in a $11.0 \%$ reduction while our $T_{\max } / T_{\min }$ perturbation results in a $11.8 \%$ reduction.

\section{Results}

\subsection{Impacts of extreme dust loading on snowmelt and hydrology using historic time series}

In the three dust scenarios under historic climate conditions, it is the highest snow accumulation areas (predominantly higher elevations) that show the greatest sensitivity in date of snow melt-out, or snow-all-gone (SAG) date to dust load and radiative forcing (Fig. 7, 1st column - Historic). Deeper snowpacks have a longer melt season and therefore a longer time period over which different melt rates can cause the snow water equivalent (SWE) amounts to diverge. Changes in date of SAG $(\triangle \mathrm{SAG})$ range from increases of up to 25 days under the LD scenario to decreases of up to 20 days under the ED scenario.

For comparison, Skiles et al. (2012) used observed energy balance data to conduct point simulations of melt season SWE evolution at the Senator Beck Basin study site. They
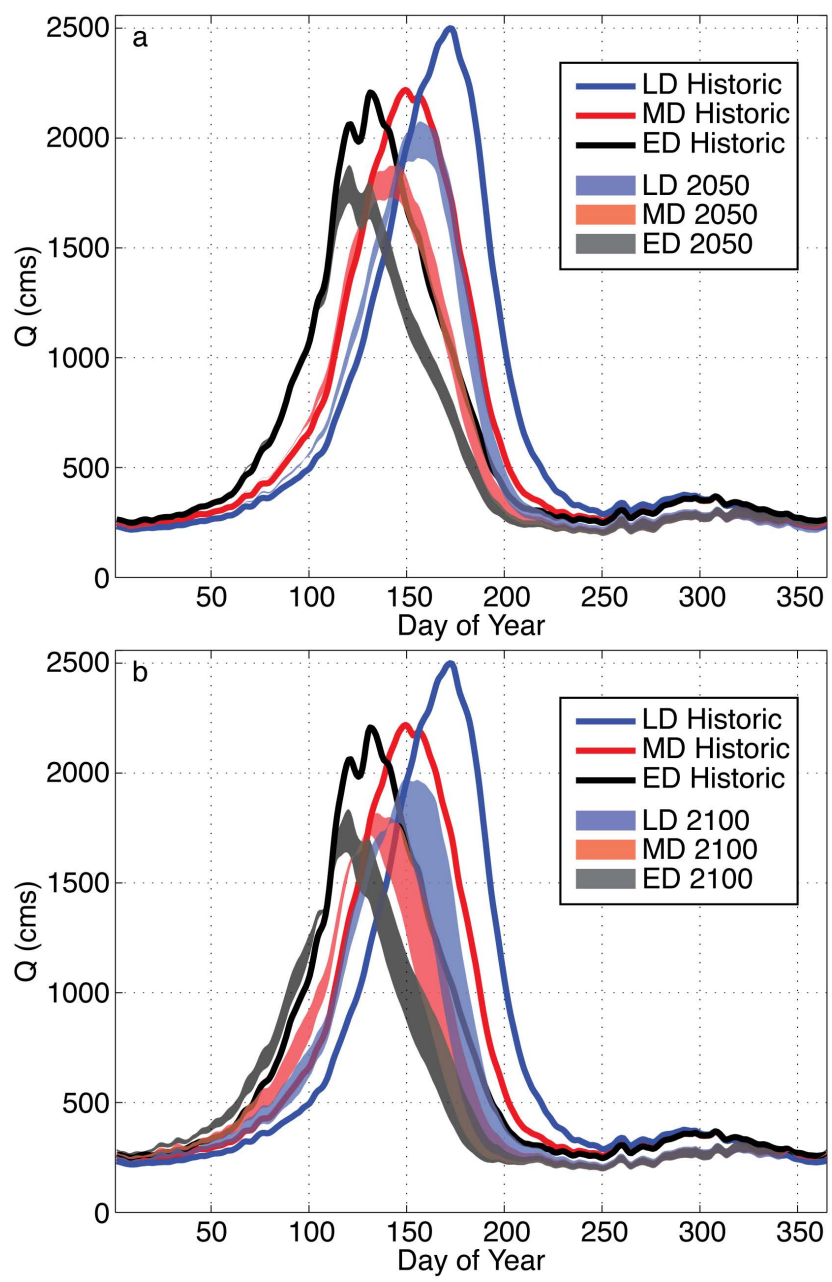

Fig. 8. (a) Mean annual hydrograph at Lees Ferry, showing moderate dust (MD), low dust (LD), and extreme dust (ED) historic traces and mean annual hydrograph for all three dust/albedo scenarios, for decade centered on 2050; colored areas show the range in hydrograph response between $\mathrm{B} 1$ and $\mathrm{A} 2$ emissions scenarios; and (b) as in (a), but for the decade ending 2100.

found that in the extreme dust years of 2009 and 2010, the snowpack melted out 50 and 43 days early, respectively, relative to a theoretical clean snowpack. This compares well in magnitude with our results from the grid cell containing the Senator Beck Basin study site, wherein the average change in SAG date between the ED and LD scenarios is 40.7 days (note that the LD scenario does not represent the albedo decay of perfectly clean snow, and thus we expect the SAG difference to be smaller than that simulated by Skiles et al., 2012).

The $88 \mathrm{yr}$ average annual hydrographs of natural flow at Lees Ferry, AZ, (essentially Lake Powell natural inflows) for the three dust albedo scenarios under the historic climate record (Fig. 8a, solid lines) and for the 2050 and 2100 climate perturbation scenarios exhibit runoff timing and volume responses to dust and climate forcings (Fig. 8a and b, shaded 
Table 5. Change in runoff $(Q)$ at Lees Ferry relative to historic climate with moderate dust loading (MD historic).

\begin{tabular}{llrrrr}
\hline & & $\begin{array}{r}\Delta Q \\
(\mathrm{BCM})\end{array}$ & $\begin{array}{c}\Delta Q \\
(\%)\end{array}$ & $\begin{array}{c}\Delta Q \\
(\mathrm{BCM})\end{array}$ & $\begin{array}{c}\Delta Q \\
(\%)\end{array}$ \\
\hline \multirow{2}{*}{ Hist } & LD & 0.98 & 4.8 & & \\
& MD & - & - & & \\
& ED & -0.09 & -0.5 & & \\
\hline \multirow{2}{*}{2050} & LD & -1.83 & -9.0 & -3.70 & -18.2 \\
& MD & -2.39 & -11.8 & -4.16 & -20.4 \\
& ED & -2.42 & -11.9 & -4.14 & -20.4 \\
\hline \multirow{2}{*}{2100} & LD & -2.44 & -12.0 & -4.46 & -21.9 \\
& MD & -2.93 & -14.4 & -4.77 & -23.4 \\
& ED & -2.94 & -14.5 & -4.74 & -23.3 \\
\hline
\end{tabular}

areas). The MD and LD historic hydrographs are identical to those published in Painter et al. (2010). The ED historic scenario produces a hydrograph that peaks a further 18 days earlier than the MD scenario and has a steeper rising limb. Both of these features were also seen in the MD/LD differences. However, whereas MD annual yield totals are $5 \%$ lower than LD due to increased sublimation and evaporative losses, ED annual yield is only reduced by $0.5 \%$ relative to MD, despite similar increases in the snow-free season (Table 5).

Consistent with Painter et al. (2010), the largest changes in yield occur in years with high flows, which result from large snow accumulations, thereby generating the greatest $\triangle \mathrm{SAG}$ (Fig. 9a and b, solid lines). Under historic climate conditions, the runoff center of mass (the day of the year when $50 \%$ of the total annual flow has passed the gage) is shifted on the order of 2 weeks later under LD relative to the MD scenario and 2 weeks earlier in the year under ED (Fig. 10a and b, solid lines).

\subsection{Dust impacts under future climate scenarios}

To evaluate combined dust and future climate impacts, we compare combinations of dust and climate scenarios to the MD historic scenario that represents current conditions. The spatial distribution of $\triangle$ SAG across the UCRB varies strongly under combinations of dust and future climate scenarios (Fig. 7, columns 2-5). While dust radiative forcing has a greater impact on the deeper snowpacks at higher elevations (due to a longer snowmelt season over which to affect divergence in melt), climate warming influences snow cover duration at all elevations due to decreases in snow accumulation (increased rain fraction and accumulation season [November through March] melt) and enhanced melt (earlier melt onset, faster melt rates). Model results show that a future warmer climate has a substantial impact on snow cover duration relative to the current climate and dust environment, with mid-century snow cover duration decreasing by 45-50 days

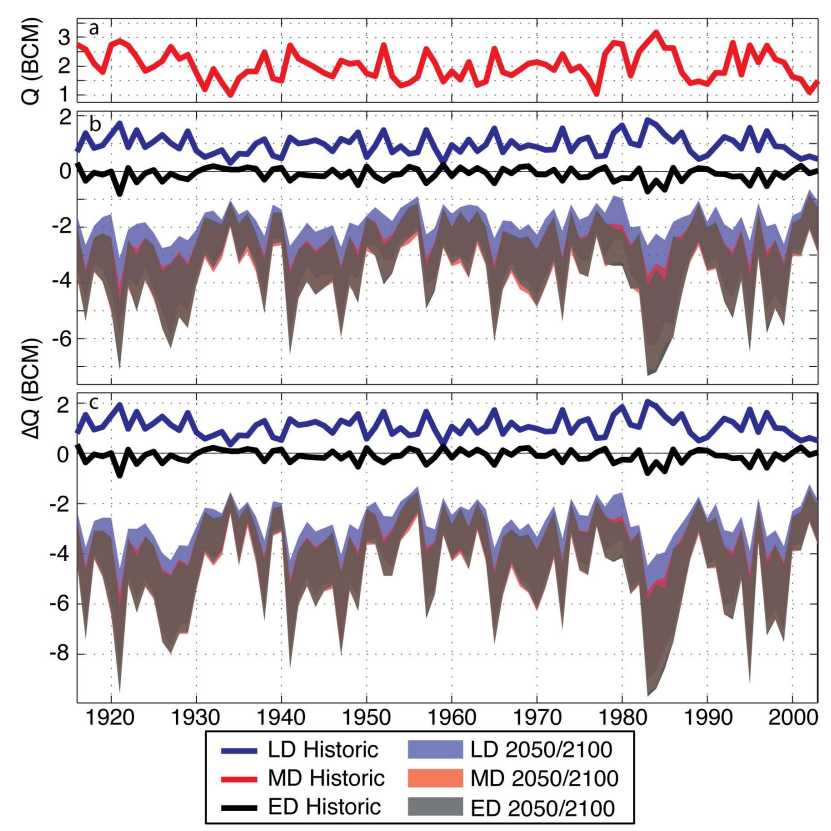

Fig. 9. (a) Annual total discharge at Lees Ferry under historic (current) climate and moderate dust deposition (MD) scenarios; (b) change in total annual discharge under lower dust (LD) and extreme dust (ED) loading scenarios, and for the decade centered on 2050; colored areas show the range between B1 and A2 emissions scenarios; (c) as in (b), but for decade ending 2100. For climate change scenarios historic years represent interannual variability for the modeled period as described in the text.

and end-of-century snow cover by up to 60 days. Interestingly, even in the warmest scenarios, the slight increases in winter precipitation in all climate scenarios result in longer snow seasons at the highest, coldest elevations. However, these areas form a very small fraction of the total snowmeltproducing area in the UCRB and do not provide much extra flow to offset the substantial changes in runoff volume from losses in snow cover elsewhere in the basin.

The combination of climate and dust scenarios for 2050 (Fig. 8a) and 2100 (Fig. 8b) produces dramatic changes in the Lees Ferry hydrograph. The shaded regions in Fig. 8 represent the range in hydrograph response bracketed by the B1 and A2 climate scenarios (Solomon et al., 2007) under the three dust scenarios. By mid-century, peak runoff moves earlier by 2-3 weeks, and peak flows decrease by 14$18 \%$ relative to the MD historic scenario (Table 5). Annual runoff volumes in 2050 decrease by $8-18 \%, 11-20 \%$, and 12-20\% for LD, MD, and ED scenarios, respectively. Endof-century hydrographs display markedly earlier snowmelt onset than the historic climate and dramatically earlier and 18-20\% reduction in peak flows. The annual runoff declines of $12-20 \%, 14-23 \%$, and 14-23\% (LD, MD, ED) suggest that flow volumes show lower sensitivity to dust loading under extreme warming than under the current climate. This sensitivity varies annually, with the largest changes (from 


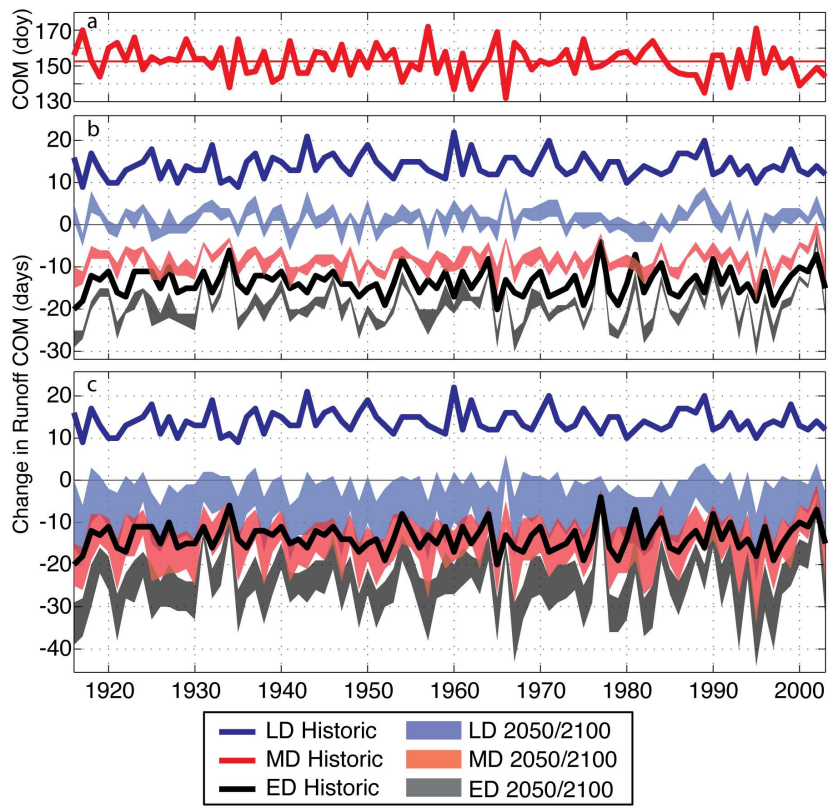

Fig. 10. As in Fig. 6, but showing (a) runoff center of mass for MD historic, and change in COM for 2050 (b) and 2100 (c).

Table 6. Day of and change in runoff center of mass (COM) relative to historic climate with moderate dust loading (MD historic).

\begin{tabular}{llrrrr}
\hline & & $\begin{array}{r}\text { COM } \\
\text { (DOY) }\end{array}$ & $\begin{array}{r}\Delta \text { COM } \\
\text { (days) }\end{array}$ & $\begin{array}{r}\text { COM } \\
(\text { DOY })\end{array}$ & $\begin{array}{r}\text { COM } \\
\text { (days) }\end{array}$ \\
\hline \multirow{2}{*}{ Hist } & LD & 167 & 14 & & \\
& MD & 153 & - & & \\
& ED & 139 & -14 & & \\
\hline \multirow{2}{*}{2050} & LD & 156 & 3 & 152 & -1 \\
& MD & 145 & -8 & 143 & -10 \\
& ED & 135 & -18 & 132 & -21 \\
\hline \multirow{2}{*}{2100} & LD & 152 & -1 & 141 & -12 \\
& MD & 142 & -11 & 133 & -20 \\
& ED & 132 & -21 & 125 & -28 \\
\hline
\end{tabular}

dust and/or climate warming) occurring in the wettest years (Fig. 9).

In contrast, center-of-mass timing maintains strong sensitivity to dust radiative forcing under all climate scenarios (Table 6; Fig. 10). Under moderate warming (B1), runoff timing ranges from 3 days later (LD) to 20 days earlier (ED). With strong warming (A2), mid-century runoff occurs 1,10 , or 21 days earlier (LD, MD, ED), and by 2100 occurs 12, 20, or 28 days earlier (LD, MD, ED). Years that exhibit early melt under the historic climate show the least sensitivity to either climate or dust forcing, as these years have low snow accumulation and therefore a shorter melt season over which to manifest melt forcings. Notably, reduced dust loading con-

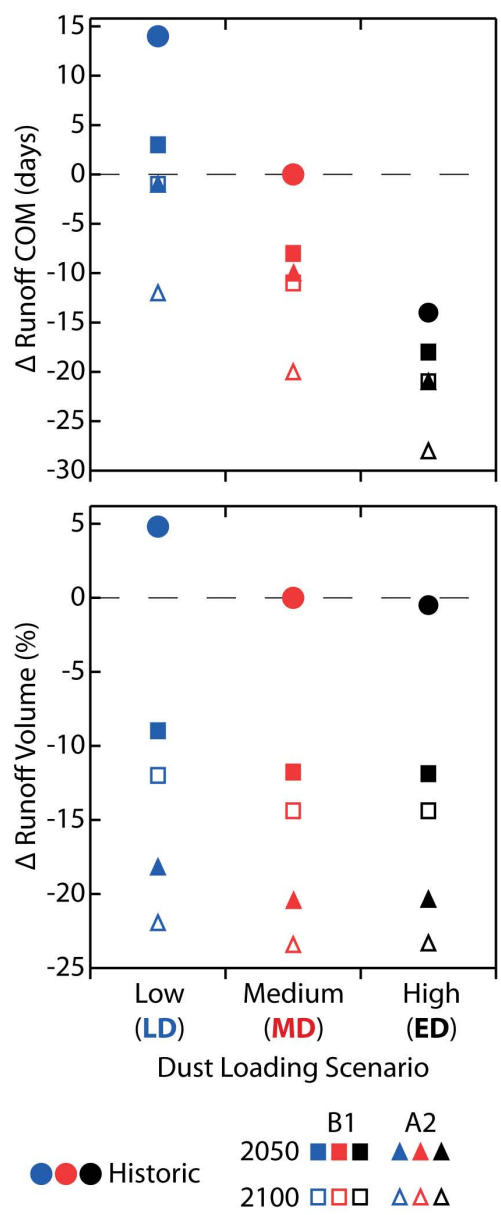

Fig. 11. Sensitivity of center-of-mass timing (a) and annual runoff volume (b) under various climate scenarios for low (LD), medium (MD), and high (ED) dust emission scenarios.

sistent with the LD scenario offsets changes in flow timing depicted by the 2050 climate warming scenarios, suggesting a possible land management avenue for coping with hydrologic impacts of moderate warming.

Sensitivities of runoff volume and timing to dust loading under combinations of dust and climate forcing are summarized in Fig. 11. As noted above, runoff timing maintains strong sensitivity to dust loading even under extreme climate warming. In contrast, changes in runoff volume appear to be dominated by climate forcing even under moderate warming scenarios.

\section{Discussion and conclusions}

Our previous study (Painter et al., 2010) that used albedo decay curves based on observations from the moderate dust years of 2005-2008 (MD scenario) indicated a strong influence of snowmelt and runoff timing (on the order of 3 weeks early) and runoff volume ( $\sim 5 \%$ decrease) by dust 
radiative forcing. The extreme dust loads observed in 2009 and 2010 provoked questions regarding their hydrologic influence, with point models indicating snow disappearance on the order of 50 days early in those years (Skiles et al., 2012).

Additionally, 2009/2010 represent potential future "normal" dust conditions, given projections of regional warming and susceptibility to dust emission in the primary dust source regions for the UCRB (Belnap et al., 2009; Munson et al., 2011). Grass and shrub coverage in regional dust source areas is likely to decline in response to increased aridity, leaving soil surfaces more frequently exposed to eolian erosion and dust emission. Dust emission modeling suggests that plant coverage decline will lead to exponential increases in dust emission under climate warming (Munson et al., 2011). The combination of dust radiative forcing on snowmelt and direct climate warming impacts on snow accumulation and melt represents an amplified, dual impact on UCRB snowpacks from regional warming. It appears that dust radiative forcing has the potential to exert greater influence on the UCRB hydrologic system in the near term than does direct warming alone (this work and Skiles et al., 2012).

Timing and magnitude of snowmelt, and therefore runoff, are very sensitive to dust radiative forcing through reduction of snow albedo. The shift in flow timing (peak and center of mass) under the ED historic scenario is similar in magnitude to the shift from LD to MD, illustrating the dominance of net solar radiation on the snow energy balance. However, the change in runoff volume at Lees Ferry between the ED and MD scenarios is much smaller than the MD to LD volume change. Under ED, snowmelt occurs in early spring when evaporative demand is lower and temperatures are generally too low to allow vegetation to begin the growing season; thus, ET losses are lower compared to MD or LD. Steltzer et al. (2009) conducted a field experiment manipulating snowmelt in a San Juan Mountains snowpack and showed that dust-accelerated melt and loss of snow cover drove tundra greening and flowering earlier in the season up until a threshold date when seasonal temperatures reached consistently above $0^{\circ} \mathrm{C}$. Snow cover removal at dates earlier than the threshold did not induce greening/flowering, and therefore would not contribute to further transpiration losses.

Under a warmer climate, however, it is probable that early spring air temperatures would be high enough to enable greening and flowering of plants uncovered by snowmelt, and thus enable ET losses to increase. The timing of ET in spring moves earlier under the warming scenarios, but does not change much when only snow albedo changes are considered without warming (Fig. 12). This effect in the model is due to increased evaporative demand from higher temperatures, not through any dynamic representation of plant phenology. It is possible that plant community response to earlier snowmelt and warmer air temperatures would differ substantially from the bulk response to evaporative drive in the VIC model, potentially resulting in greater ET losses from accelerated or early onset of plant growth.

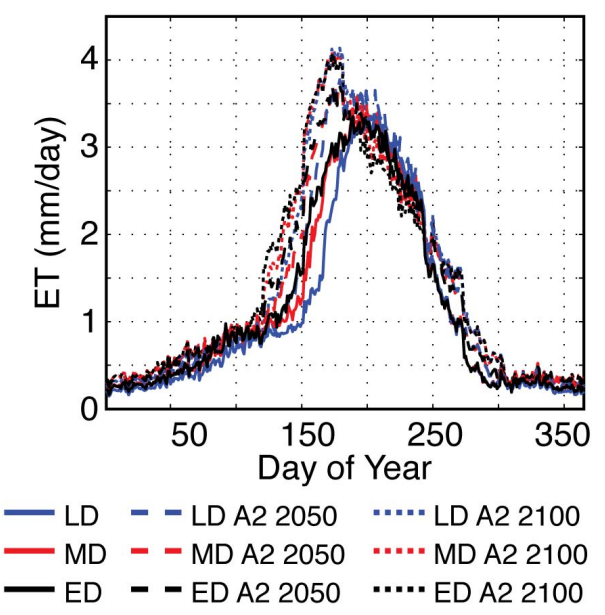

Fig. 12. Simulated median daily evapotranspiration over all model years for the grid cell containing Senator Beck Basin. Only the A2 climate scenario is shown, for clarity.

The timing of snowmelt onset in the 2050 scenarios appears to still be strongly controlled by dust loading, as the spring hydrograph rise changes little in response to climate forcing for each individual dust situation, with only the LD run showing much response by melt onset timing to warming (Fig. 8a). These results are consistent with the point snowmelt modeling results of Skiles et al. (2012). Under the 2100 climate scenario, however, spring runoff begins earlier in the warmer climate regardless of the dust situation: it appears that the extreme warming represented by the 2100 perturbations overwhelms dust forcing of snowmelt onset (Fig. 8b).

The sensitivity of runoff center-of-mass timing to dust radiative forcing appears undiminished by climate warming. Indeed, COM timing appears to be about equally sensitive to warming and dust scenarios (Figs. 10 and 11; Table 6). The seasonal timing of runoff is of particular interest to those water users whose supply comes directly from the higher reaches of the UCRB. Reservoir storage there is typically modest and the seasonal snowpack represents an important natural storage reservoir in the system. Delayed snowmelt can have important benefits to water delivery obligations and late season flow volumes. The lower basin, which relies on the enormous storage capacity in the two largest reservoirs in the United States, lakes Powell and Mead, is affected primarily by the potential for dust-induced changes to annual runoff volume.

Changes in runoff volume are largely dominated by climate warming rather than dust loading in both the 2050 and 2100 runs, though some substantial sensitivity remains under the B1 2050 scenario, wherein dust loading equivalent to LD saves on the order of $3 \%$ of current annual flow (Fig. 9; Table 5). Runoff losses of the magnitude indicated by the ED 2050 or by any of the 2100 A2 scenarios would represent an 
unmanageable water supply condition, with devastating effects on the regional economy and ecosystems.

One way to examine the relative changes in runoff timing and volume in the future climate/dust results is to treat the different dust loading scenarios as mitigation scenarios, i.e., with an eye toward influencing dust emission in order to add resilience to the Colorado River system. The primary influence of different dust scenarios under the modeled future climates is exerted on flow timing (Fig. 10; Table 6). Recovery to pre-settlement dust conditions (LD scenario) would more than offset warming-induced flow timing impacts in 2050 and would offset warming impacts under the B1 scenario in 2100. Maintenance of MD conditions would offset about 10 days of runoff timing change in 2050 and up to 20 days in 2100 (A2).

Three factors are required for dust production: winds sufficient to suspend soil particles, exposed soils (often through the reduction of vegetation) and soils having characteristics making them vulnerable to wind erosion. Winds speeds at the ground level can be reduced through physical windbreaks or vegetation. Vegetative cover reduces soil exposure, and thus sites currently dominated by annual plants (e.g., abandoned croplands, heavily disturbed sites) can be rehabilitated by establishment of perennial grasses and shrubs that provide protection even in drought years. Most dryland soils are stable until disturbed (Field et al., 2010), and thus reduced surface disturbance (e.g., livestock grazing, off-road vehicles, agricultural activities, fire) in lower elevation regions, especially during drought years, can be highly effective in reducing dust production.

It is clear, from this study and others, that radiative forcing by dust exerts a strong influence on snowmelt in the UCRB. The science quantifying the impacts on snowmelt and date of snow disappearance at the point scale is robust. Our ability to extend these impacts to the full UCRB and to quantify impacts on runoff volume is currently limited by the physics employed in hydrologic models and by the limitations of snow and meteorological observation networks and model driving data. In particular, we lack a dynamic hydrologic model in which the atmosphere can respond to changes in snow cover and thermal conductivity. In this context, our approach has been to explore the system response to dust and climate perturbations via a sensitivity approach, wherein the snow energy balance response and subsequent early snowmelt and runoff are consistent with detailed field observations, but changes in total runoff volume due to dust radiative forcing are more difficult to verify.

Individual and/or combined forcing of snowmelt in the UCRB by dust and regional warming are likely to push the hydrologic system to the extremes of the historic period of record and beyond, which will present an enormous challenge to water supply monitoring, forecasting, and management. To effectively manage the new realities of climate and dust forcings, we need expanded energy balance monitoring, SWE and albedo mapping, and process-based modeling. Re- cent extremes in dust deposition (2009-2010) and extremes in flood and drought represented both in climate scenarios and in paleohydrologic records should serve as an urgent call to action for development of these new tools.

\section{Conclusions}

Our recent work has shown that decreased snow albedo from dust loading to the mountains of Colorado of the magnitude observed in 2005-2008 shortens snow cover duration by several weeks relative to conditions prior to westward expansion of the United States in the mid-1800s, and causes peak runoff from the UCRB to occur an average of 3 weeks earlier. Increased evapotranspiration losses due to the longer snow-free season were estimated to decrease annual runoff by about $5 \%$ of the annual average flow. We developed a new snow albedo decay parameterization based on observations of the much higher dust loading observed in 2009/10, and examine the low, moderate, and extreme dust/snow albedos in combination with both historic climate forcing and two future climate scenarios. Extreme dust shifts peak snowmelt an additional 3 weeks earlier to a total of 6 weeks earlier than pre-disturbance, and reduces annual flow volume an additional $1 \%$ (6\% compared to pre-disturbance). Sensitivity of flow timing to dust radiative forcing is maintained under future climate scenarios, but the sensitivity of flow volume appears to decrease with increased climate forcing. These results have implications for water management and suggest that dust abatement efforts could be an important component of any climate adaptation strategies in the UCRB.

Acknowledgements. Thanks to C. Landry and the Center for Snow and Avalanche Sciences for sustained snow energy balance monitoring, L. Brekke at the Bureau of Reclamation for providing regridded climate model projections, to $\mathrm{M}$. Elsner and A. Hamlet for VIC model technical assistance and discussions, and to R. Reynolds for a technical review. We also thank T. Meixner and an anonymous reviewer for substantive critiques that improved the readability and clarity of the manuscript. This research was funded by the NOAA Climate Program Office through the Western Water Assessment RISA at CIRES, University of Colorado-Boulder, and by NASA under Interdisciplinary Sciences grant \#NNX10AO97G. Part of this work was performed at the Jet Propulsion Laboratory, California Institute of Technology, under a contract with NASA.

Edited by: M. Hrachowitz

\section{References}

Bales, R. C., Molotch, N. P., Painter, T. H., Dettinger, M. D., Rice, R., and Dozier, J.: Mountain hydrology of the western United States, Water Resour. Res., 42, 8432, doi:10.1029/2005WR004387, 2006. 
Barnett, T. P. and Pierce, D. W.: Sustainable water deliveries from the Colorado River in a changing climate, P. Natl. Acad. Sci. USA, 106, 7334-7338, doi:10.1073/pnas.0812762106, 2009.

Barnett, T. P., Adam, J. C., and Lettenmaier, D. P.: Potential impacts of a warming climate on water availability in snow-dominated regions, Nature, 438, 303-309, doi:10.1038/nature04141, 2005.

Belnap, J., Reynolds, R. L., Reheis, M. C., Phillips, S. L., Urban, F. E., and Goldstein, H. L.: Sediment losses and gains across a gradient of livestock grazing and plant invasion in a cool, semiarid grassland, Colorado Plateau, USA, Aeolian Research, 1, 2743, doi:10.1016/j.aeolia.2009.03.001, 2009.

Brahney, J., Ballantyne, A. P., Sievers, C., and Neff, J. C.: Increasing $\mathrm{Ca} 2+$ deposition in the western US: The role of mineral aerosols, Aeolian Research, 10, 77-87, doi:10.1016/j.aeolia.2013.04.003, 2013.

Bureau of Reclamation, SECURE Water Act Section 9503(c) Reclamation Climate Change and Water, Report to Congress, 2011a.

Bureau of Reclamation: Colorado River Basin Water Supply and Demand Study, 2011b.

Cayan, D. R., Das, T., Pierce, D. W., Barnett, T. P., Tyree, M., and Gershunov, A.: Future dryness in the southwest US and the hydrology of the early 21 st century drought, P. Natl. Acad. Sci. USA, 107, 21271-21276, doi:10.1073/pnas.0912391107, 2010.

Christensen, N. S. and Lettenmaier, D. P.: A multimodel ensemble approach to assessment of climate change impacts on the hydrology and water resources of the Colorado River Basin, Hydrol. Earth Syst. Sci., 11, 1417-1434, doi:10.5194/hess-11-14172007, 2007.

Christensen, N. S., Wood, A. W., Voisin, N., Lettenmaier, D. P., and Palmer, R. N.: The effects of climate change on the hydrology and water resources of the Colorado River basin, Climatic Change, 62, 337-363, 2004.

Colorado Water Conservation Board: Colorado River Water Availability Study Phase I Report, March 2012.

Dominguez, F., Rivera, E., Lettenmaier, D. P., and Castro, C. L.: Changes in winter precipitation extremes for the western United States under a warmer climate as simulated by regional climate models, Geophys. Res. Lett., 39, 1-7, doi:10.1029/2011GL050762, 2012.

Field, J. P., Belnap, J., Breshears, D. D., Neff, J. C., Okin, G. S., Whicker, J. J., Painter, T. H., Ravi, S., Reheis, M. C., and Reynolds, R. L.: The ecology of dust, Front. Ecol. Environ., 8, 423-430, doi:10.1890/090050, 2010.

Hamlet, A. F., Mote, P. W., Clark, M. P., and Lettenmaier, D. P.: Effects of Temperature and Precipitation Variability on Snowpack Trends in the Western United States, J. Climate, 18, 4545-4561, 2005.

Hamlet, A. F., Mote, P. W., Clark, M. P., and Lettenmaier, D. P.: Twentieth-Century Trends in Runoff, Evapotranspiration, and Soil Moisture in the Western United States*, J. Climate, 20, 1468-1486, doi:10.1175/JCLI4051.1, 2007.

Knowles, N., Dettinger, M., and Cayan, D. R.: Trends in snowfall versus rainfall in the western United States, J. Climate, 19, 45454559, 2006.

Lawrence, C. R. and Neff, J. C.: The contemporary physical and chemical flux of aeolian dust: A synthesis of direct measurements of dust deposition, Chem. Geol., 267, 46-63, doi:10.1016/j.chemgeo.2009.02.005, 2009.
Lawrence, C. R., Painter, T. H., Landry, C. C., and Neff, J. C.: Contemporary geochemical composition and flux of aeolian dust to the San Juan Mountains, Colorado, United States, J. Geophys. Res., 115, 1-15, doi:10.1029/2009JG001077, 2010.

Liang, X., Lettenmaier, D., and Wood, E.: A simple hydrologically based model of land surface water and energy fluxes for general circulation models, J. Geophys. Res, 99, 14415-14428, 1994.

McCabe, G. J. and Wolock, D. M.: Warming may create substantial water supply shortages in the Colorado River basin, Geophys. Res. Lett., 34, L22708, doi:10.1029/2007GL031764, 2007.

Mote, P. W.: Climate-Driven Variability and Trends in Mountain Snowpack in Western North America*, J. Climate, 19, 62096220, doi:10.1175/JCLI3971.1, 2006.

Mote, P. W., Hamlet, A. F., Clark, M. P., and Lettenmaier, D. P.: Declining mountain snowpack in western North America, B. Am. Meteorol. Soc., 86, 39-49, doi:10.1175/BAMS-86-1-39, 2005.

Munson, S. M., Belnap, J., and Okin, G. S.: Responses of wind erosion to climate-induced vegetation changes on the Colorado Plateau., P. Natl. Acad. Sci. USA, 108, 3854-3859, doi:10.1073/pnas.1014947108, 2011.

Nakicenvoic, N., Alcamo, J., Davis, G., de Vries, B., Fenhann, J., Gaffin, S., Gregory, K., Grübler, A., Jung, T. Y., Kram, T., La Rovere, E. L., Michaelis, L., Mori, S., Morita, T., Pepper, W., Pitcher, H., Price, L., Riahi, K., Roehrl, A., Rogner, H. H., Sankovski, A., Schlesinger, M., Shukla, P., Smith, S., Swart, R., van Rooijen, S., Victor, N., and Dadi, Z.: Special Report on Emissions Scenarios. A Special Report of Working Group III of the Intergovernmental Panel on Climate Change, Cambridge University Press: Cambridge, 599 pp., 2000.

Neff, J. C., Ballantyne, A. P., Farmer, G. L., Mahowald, N. M., Conroy, J. L., Landry, C. C., Overpeck, J. T., Painter, T. H., Lawrence, C. R., and Reynolds, R. L.: Increasing eolian dust deposition in the western United States linked to human activity, Nat. Geosci., 1, 189-195, doi:10.1038/ngeo133, 2008.

Nijssen, B., Donnell, G., Hamlet, A., and Lettenmaier, D. P.: HYDROLOGIC SENSITIVITY OF GLOBAL RIVERS TO CLIMATE CHANGE, Climatic Change, 50, 143-175, 2001.

Oerlemans, J. and Klok, E.: Energy Balance of a Glacier Surface: Analysis of Automatic Weather Station Data from the Morteratschgletscher, Switzerland, Arctic, Antarctic, and Alpine Research, 34, 477-485, 2002.

Painter, T. H., Barrett, A. P., Landry, C. C., Neff, J. C., Cassidy, M. P., Lawrence, C. R., McBride, K. E., and Farmer, G. L.: Impact of disturbed desert soils on duration of mountain snow cover, Geophys. Res. Lett., 34, 1-6, doi:10.1029/2007GL030284, 2007.

Painter, T. H., Deems, J. S., Belnap, J., Hamlet, A. F., Landry, C. C., and Udall, B.: Response of Colorado River runoff to dust radiative forcing in snow, P. Natl. Acad. Sci., 107, 17125-17130, doi:10.1073/pnas.0913139107, 2010.

Painter, T. H., Skiles, S. M., Deems, J. S., Bryant, A. C., and Landry, C. C.: Dust radiative forcing in snow of the Upper Colorado River Basin: 1. A 6 year record of energy balance, radiation, and dust concentrations, Water Resour. Res., 48, W07521, doi:10.1029/2012WR011985, 2012a.

Painter, T. H., Bryant, A. C., and Skiles, S. M.: Radiative forcing by light absorbing impurities in snow from MODIS surface reflectance data, Geophys. Res. Lett., 39, 1-7, doi:10.1029/2012GL052457, 2012b. 
Pierce, D. W., Westerling, A. L., and Oyler, J.: Future humidity trends over the western United States in the CMIP5 global climate models and variable infiltration capacity hydrological modeling system, Hydrol. Earth Syst. Sci., 17, 1833-1850, doi:10.5194/hess-17-1833-2013, 2013.

Rangwala, I., Barsugli, J., Cozzetto, K., Neff, J., and Prairie, J.: Mid-21st century projections in temperature extremes in the southern Colorado Rocky Mountains from regional climate models, Clim. Dynam., 39, 1823-1840, doi:10.1007/s00382-0111282-z, 2012.

Ray, A. J., Barsugli, J. J., and Averyt, K. A.: Climate Change in Colorado Management and Adaptation Climate Change in Colorado Lead Authors Authors, Boulder, CO, 2008.

Reynolds, R. L., Mordecai, J. S., Rosenbaum, J. G., Ketterer, M. E., Walsh, M. K., and Moser, K. A.: Compositional changes in sediments of subalpine lakes, Uinta Mountains (Utah): evidence for the effects of human activity on atmospheric dust inputs, J. Paleolimnol., 44, 161-175, doi:10.1007/s10933-009-9394-8, 2009.

Seager, R., Ting, M., Held, I., Kushnir, Y., Lu, J., Vecchi, G., Huang, H.-P., Harnik, N., Leetmaa, A., Lau, N.-C., Li, C., Velez, J., and Naik, N.: Model projections of an imminent transition to a more arid climate in southwestern North America, Science, 316, 11811184, doi:10.1126/science.1139601, 2007.

Seager, R., Ting, M., Li, C., Naik, N., Cook, B., Nakamura, J., and Liu, H.: Projections of declining surface-water availability for the southwestern United States, Nature Clim. Change, 3, 1-5, doi:10.1038/nclimate1787, 2012.

Skiles, S. M., Painter, T. H., Deems, J. S., Bryant, A. C., and Landry, C. C.: Dust radiative forcing in snow of the Upper Colorado River Basin: 2. Interannual variability in radiative forcing and snowmelt rates, Water Resour. Res., 48, W07522, doi:10.1029/2012WR011986, 2012.
Solomon, S., Qin, D., Manning, M., Chen, Z., Marquis, M., Averyt, K. B., Tignor, M., and Miller, H. L. (Eds.): Contribution of Working Group I to the Fourth Assessment Report of the Intergovernmental Panel on Climate Change, Cambridge University Press, Cambridge, United Kingdom and New York, NY, USA, 996 pp., 2007.

Steenburgh, W. J., Massey, J. D., and Painter, T. H.: Episodic Dust Events of Utah's Wasatch Front and Adjoining Region, J. Appl. Meteorol. Clim., 51, 1654-1669, doi:10.1175/JAMC-D-12-07.1, 2012.

Steltzer, H., Landry, C., Painter, T. H., Anderson, J., and Ayres, E.: Biological consequences of earlier snowmelt from desert dust deposition in alpine landscapes, P. Natl. Acad. Sci. USA, 106, 11629-11634, doi:10.1073/pnas.0900758106, 2009.

Su, F., Adam, J. C., Trenberth, K. E., and Lettenmaier, D. P.: Evaluation of surface water fluxes of the pan-Arctic land region with a land surface model and ERA-40 reanalysis, J. Geophys. Res., 111, 1-16, doi:10.1029/2005JD006387, 2006.

Thornton, P. E. and Running, S. W.: An improved algorithm for estimating incident daily solar radiation from measurements of temperature, humidity, and precipitation, Agr. Forest Meteorol., 93, 211-228, doi:10.1016/S0168-1923(98)00126-9, 1999.

Vano, J. A., Das, T., and Lettenmaier, D. P.: Hydrologic Sensitivities of Colorado River Runoff to Changes in Precipitation and Temperature, J. Hydrometeorol., 13, 932-949, doi:10.1175/JHM-D11-069.1, 2012.

Yu, H., a Remer, L., Chin, M., Bian, H., Tan, Q., Yuan, T., and Zhang, Y.: Aerosols from overseas rival domestic emissions over North America, Science, 337, 566-569, doi:10.1126/science.1217576, 2012. 